\title{
Exploring the impact of Feuerstein's Instrumental Enrichment Programme on the cognitive development of prospective mathematics educators
}

\author{
$M_{M}$ KLOPPERS ${ }^{*}$ AND MM GROSSER
}

\begin{abstract}
In this article the researchers report on the findings obtained from a sequential explanatory mixed method study through testing and narratives in order to determine the extent to which 24 prospective Mathematics educators at a South African university enrolled for a BEd-degree possess cognitive skills, and to establish the potential of the Feuerstein Instrumental Enrichment programme (FIE) to develop and improve the cognitive skills of the said prospective educators. Results indicated that there is a need for improving the cognitive skills of the prospective Mathematics educators and that the FIE programme possesses the latent potential to improve and develop cognitive skills.

The significance of this research lies in the contribution it makes in particular to equip lecturers involved in educator training with knowledge regarding the merits of the Feuerstein FIE programme for improving cognitive performance.
\end{abstract}

Keywords: Cognitive skills, cognitive development, intervention, mediation, cognitive development, Instrumental Enrichment.

Disciplines: Mathematics teaching, Cognitive development, Teacher education.

\section{Introduction and problem statement}

The critical outcomes, as formulated in the National Curriculum Statement of South Africa, envisages learners who are, among others, competent in the solving of problems, effective in the collection, organizing and managing of activities and successful in evaluating and applying information critically (Department of Education, 2003a, p. 2). In achieving these critical outcomes, the Government wishes to turn schools into "thriving centers of excellence" (Zuma, quoted by Davis, 2009). This corresponds with an aim of the Constitution of the Republic of South Africa, namely to "improve the quality of life of all citizens and free the potential of each person" (Department of Education, 2003a, p. 1), to enable learners to think "smarter" than was the case in the past (Pithers \& Soden, 2000, p. 237) and to equip learners with skills to enable them to decipher, question, validate and reason through the substantiality or validity of information (Barnes, 2005, p.12).

Ms MM (Magda) Kloppers is a lecturer in teaching and learning, School of Educational Sciences, North-West University: Vaal Triangle Campus, E-mail: Magda.Kloppers@nwu.ac.za.

Prof MM (Mary) Grosser is associate professor in teaching and learning, School of Educational Sciences, North-West University: Vaal Triangle Campus, Tel: +27 16910 3063; E-mail: Mary.Grosser@nwu.ac.za

TD The Journal for Transdisciplinary Research in Southern Africa, 6(2) December 2010, pp. 359 - 378. 
However, the poor performance of learners in South Africa is highlighted by the Third International Mathematics and Science Study (TIMSS) and the Third International Mathematics and Science Study-Repeat (TIMSS-R) which both report deficiencies with regard to higher-order skills, inter alia including the ability to think critically. Maree, Molepo, Owen and Ehlers (2005, p. 124), Howie (2007) and Van der Walt and Maree (2007, p. 223) indicate that the aforementioned ideals have not yet become reality. The TIMSS studies revealed that the South African Grade 8 learners had the lowest scores in Science and Mathematics, two subjects which require well developed cognitive skills such as application and reasoning. The strong cognitive focus required for performance in Mathematics is clear, according to the National Curriculum Statement for Mathematics. Learners should demonstrate the ability to think logically, analytically, holistically and laterally and be capable of applying knowledge from familiar to unfamiliar situations (Department of Education, 2003a, p. 5).

In support of the argument of Feuerstein, (2007, p.5), the researchers agree that the inability of learners to deal with the cognitive demands placed on them can inter alia be attributed to poorly developed cognitive skills and that educators themselves need to possess cognitive skills before they can nurture these skills among their learners (Lombard \& Grosser, 2004, p. 213 ). As the classroom is the most obvious place to deal with the development of cognitive skills, the poor TIMSS results could indicate that educators are not succeeding in equipping learners with cognitive skills (Lombard \& Grosser, 2008, p. 572). Prospective educators therefore need to be equipped with the necessary cognitive skills to enable them to develop these skills in their learners.

The researchers' own observations as ex-teachers and presently as lecturers revealed that most of the learners and students do not possess adequate cognitive skills which attribute to learners being unmotivated, negative and passive (Peretti \& Austin, 1980, p. 225; Feuerstein, 1982, p. 37). Our observations informed our conclusion that purposeful efforts should be undertaken to establish the cognitive skills of prospective educators and to recommend ways in which cognitive skills could be enhanced. Haywood, Burns, Arbitman-Smith and Delclos (1984, p. 22), Thornton (2002, p. 7-41), Bjorklund (2005, p. 58) and Bauer (2006: p. 128-131) are of the opinion that cognitive skills can be acquired systematically over time even if these skills were not developed during the pre-school years. This research set out to determine whether this statement holds true.

\section{Cognitive Development and the Feuerstein Instrumental Enrichment Programme}

The aim of the teaching of thinking should be to teach learners to think independently and effectively on their own (Beyer, 1991, p. 8; Engelbrecht, 1995, p.11-12; Schraw \& Olafson, 2003, p.196; Feuerstein, 2008). It is therefore important that educators themselves should function on an abstract level of thinking in order to create classroom climates conducive to the development of cognitive skills (Wragg \& Brown, 2001, p. 1). Learning should include mediation and negotiations, and the educators should act as facilitators of learning to encourage learners to become self-regulated and to construct knowledge with understanding independently (Gouws, 1998, p. 72, 73; Doolittle, 2000; Eggen \& Kauchak, 2004, p. 28; Woolfolk, 2004, p. 323; Bjorklund, 2005, p. 81; Langford, 2005, p. 234, 235; Kok, 2007, p. 64-44; Ormrod, 2008, p. 29, 196).

Cognitive development focuses among others, on the nurturing of skills to compare, classify, categorize, analyse, synthesize, evaluate, solve problems, make decisions and reason (Sigel, 1991, p. 43; Eggen \& Kauchak, 2004, p. 335). The mentioned skills can be divided into two 
important components, namely cognitive and meta-cognitive thinking skills and strategies (Beyer, 1987, p. 17; Monteith, 2002, p. 97; Halpern, 2007, p. 10). Cognitive thinking skills are used to create meaning and involve complex strategies such as decision-making, problemsolving and conceptualization, as well as more discrete, less complex skills like analysis or synthesis, reasoning skills and more advanced critical thinking skills which are used to distinguish between relevant and non-relevant information (Beyer, 1987, p. 17; Monteith, 2002, p. 97; Halpern, 2007, p. 10). Meta-cognitive thinking skills are used to direct and control cognitive skills (Ormrod, 2008, p. 266-277) and are linked to the reflective skills of planning, monitoring and evaluating the learning progress (Thornton, 2002, p. 102; Grabe \& Grabe, 2004, p. 47-49; Van den Berg, 2004, p. 279-280; Gelter, 2005, p. 337; Bereiter, 2006, p. 14; Kok, 2007, p. 28-30).

Rudd (2007, p. 46) claims that thinking should be taught directly in order for learners to reach their full potential, and therefore educators should be familiar with different approaches to the development of thinking skills. With regard to the cognitive development of learners, the role of the educator receives prominent attention. Educators should create safe environments, assist learners to discover their own thinking abilities and reflect on them, teach mutual relationships and create opportunities for learners to act on their own thinking (Wragg \& Brown, 2001, p. 1; Singh, Granville \& Dika, 2002, p. 328, Le Roux, Olivier \& Murray, 2004, p. 89; Winstead, 2004, p. 43). Many learners struggle to think independently of the teacher and to apply knowledge outside the content of their text books (Engelbrecht, 1995, p. 11-12; Sonn, 2000, p. 259; Schraw \& Olafson, 2003, p. 178-293; Elder \& Paul, 2004, p. 36). More complex and sophisticated ways of reasoning and problem-solving should therefore be developed (Pratt, 2005) and learners should be granted the opportunity to explain their thinking and be active participants who take responsibility for their own learning (Vakalisa, 2007, p. 5). Educators can no longer be only the conveyers of knowledge, but should be aware of the way their learners think and be able to build bridges from the way learners think to more complex and sophisticated ways of thinking (Pratt, 2005). Haywood et al. (1984, p. 20) and Lombard and Grosser $(2004$, p. 572) are of the opinion that educators do not possess the ability to utilize the process of formal organized thinking and are therefore not capable of conveying it to their learners. Furthermore, educators should purposefully create learning environments which cherish in-depth learning and higher-order thinking (Sing \& Khine, 2008, p. 288, 289).

In addition to this, Fisher (1990. p. 4), Vygotsky (in Ormrod, 1995, p. 58-62), Schayer (2000, p. 36-59), Eggen and Kauchak (2004, p. 55-57), Donald et al. (2004, p. 69), Woolfolk (2004, p. 46-52), Langford (2005, p. 46-52), Ormrod (2008, p. 39-43) and Feuerstein (in Wittrock, 1991 , p. 82) argue that cognitive structures can inter alia be changed through a meditated learning approach to teaching. Feuerstein, Miller, Hoffman, Rand, Mintzker and Jensen (1981, p. 272) define mediated learning experiences as the conveyance of general cognitive structures from the experienced to the inexperienced, less capable person. If learners are exposed to mediated learning experience from a young age, they will have cognitive structures at their disposal which will enable them to organize, join, connect and relate stimulus information (Feuerstein et al., 1981, p. 272; Feuerstein, Hoffman, Jensen \& Rand, 1985, p. 47; Fraser, 2006, p. 9). A mediated learning approach expects of learners to think actively and independently (Cole, Hung, McCaslin \& Hickley, quoted by Schraw \& Olafson, 2003, p. 181). In essence, mediation implies that teaching and learning should clarify the intent and meaning of what is to be learned and enable learners to apply what they have learned. In addition to this, teaching and learning should create individualized and challenging opportunities for learners to become competent, self-regulated learners who can share information with others (Falik, 2001). 
Studies done at school level and Higher Education level in, inter alia, Israel (Feuerstein et al., 1981, p. 282; Savell, Twohig \& Rachford, 1986, p. 390; Kozulin, 2008), The United States of America (Toomey, Smyth, Warner \& Fraser, 2000), New Zealand (Sharron, 1987, p. 236), Venezuela (Sharron, 1987, p. 15), Cleveland and Bahia (Kozulin, 2008) and in South Africa (Feuerstein et al., 1981, p. 282; Savell et al., 1986, p. 390; Kozulin, 2008) have shown that the mediated learning approach of Reuven Feuerstein possesses the latent potential to develop and improve thinking skills. Reuven Feuerstein holds the belief that intelligence is not a fixed entity and can be nurtured (in Matthews, 2001, p. 150). In addition to this, Feuerstein (2008) argues that a mediated learning approach can equip learners of any age with concepts, strategies and skills to repair cognitive deficiencies and to think independently (Feuerstein, 2008). Furthermore, the relevance of the FIE programme for South African pre-service teachers is documented in a study conducted by Skuy, Lomofsky, Fridjhon and Green (1993, p. 92-108). This particular study reports on the merits of the FIE programme for educationally disadvantaged students from a "coloured" community studying towards a teaching qualification at a former teacher training college in South Africa (Skuy et al., 1993, p.95). However, no studies documenting the success of Feuerstein's mediated learning approach with pre-service teachers studying towards a teaching qualification at university level could be located. Therefore this research makes an important contribution by highlighting the merits that the FIE programme hold for the training of educators studying towards a BEd-degree at a university.

Reuven Feuerstein structured his mediated learning approach to cognitive development in an intervention programme, the FIE programme which consists of fourteen content-free instruments that each comprise a number of pencil and paper exercises. The FIE programme is not culturally biased, and no prior knowledge or subject knowledge is required for participating in the programme. The programme creates a safe environment where intrinsic motivation is developed and enhanced through reflective thinking (Egozi, 1994, p. 361). The posing of questions during mediation plays an important role in the development of thinking (Rotterdam, 2000, p.6) and this technique is used in all the FIE lessons. The main purpose of the instruments is to improve the cognitive functioning of the learner irrespective of age, culture and socio-economic environment by increasing intrinsic motivation and promoting reflective thinking through which autonomous cognitive behaviour is learned (Wittrock, 1991, p. 83). The programme exercises address cognitive skills such as classification, spatial relationship, planning, organizing, inductive and deductive reasoning (Link, 1991, p. 11; Feuerstein, Rand, Hoffman \& Miller, 1983, p.1 26). In particular, the programme focuses on the factors leading to poor cognitive development and attempts to change the passive dependent cognitive style of the learner into an active independent cognitive style (Feuerstein et al., 1983, p. 1). Learners demonstrate cognitive deficiencies when they find it problematic to gather, organize and use information, are impulsive and do not possess strategies or structures for thinking (Fisher, 1990, p. 132; Feuerstein, 2007, p. 5). These deficiencies can impact on the input, elaboration or output level of the learning process (Nickerson, Perkins \& Smith, 1985, p. 152). Cognitive deficiencies in the input phase imply blurred and sweeping perceptions that lead to unplanned, impulsive, inaccurate and unsystematic learning. Furthermore, learners cannot work with two or more sources of information at a time (Feuerstein et al., 1983, p. 73; Feuerstein et al., 1985, p. 52-53; Feuerstein, 2007, p. 5). If learners lack cognitive functions in the elaboration phase they experience difficulties in planning their actions, defining problems and distinguishing between relevant and irrelevant cues for solving a problem (Feuerstein et al., 1983, p. 73-74; Feuerstein 2007, p. 5). Impaired cognitive functions in the output phase are recognized by trial and error responses and the inability to communicate responses accurately (Feuerstein et al., 1983, p. 74; Feuerstein, 2007, p. 5). 
In the context of this study the researchers focused on two instruments in the FIE programme, namely Organization of Dots and Analytic Perceptions. Organization of Dots aims at empowering learners to organize, plan, categorize, analyse and summarize spontaneously, restrict impulsive behaviour, improve problem-solving techniques and social interaction, and develop reflexive processes. Cognitive functions which are developed by Analytic Perception are spontaneous comparison, identifying relationships and categorizing (Feuerstein, 1996).

\section{Research Framework and Design}

Framed within a pragmatic paradigm, this pilot study was explanatory in nature. Sequential explanatory mixed-method research involving a quantitative and qualitative method of data collection was utilized (Ivankova, Creswell \& Plano-Clark, 2007, p. 254-265). Quantitative data collection by means of testing and qualitative data collection through participant narratives characterized the research process. In the context of this study, the test results were obtained and analysed where after the participants were requested to write down their personal experiences with the FIE programme in the form of a narrative. The narratives were analysed and used to gain a deeper understanding of the test results. Primarily, the focus was on the quantitative data while the qualitative data was used in a secondary role to explain and better understand the test results obtained (McMillan \& Schumacher, 2006, p.28).

As part of the quantitative component, a pre-experimental pre-test post-test research design was used with two groups of randomly assigned participants, namely Group 1 and Group 2. The verbal and non-verbal reasoning tests of the DAT-L test battery were used to determine the extent to which cognitive skills were developed among the participants. The pre-test was done with the entire group of participants before the commencement of the study to determine the cognitive skills of the group before the application of the FIE intervention programme. The researchers personally exposed both groups to intervention with the FIE programme on rotational basis for a period of twelve hours over six weeks in an attempt to develop and/or improve thinking skills. After the implementation of the intervention, each of the groups was tested again with the same verbal and nonverbal reasoning DAT-L tests to determine whether the intervention programme had developed and/or improved thinking skills. Furthermore, after the six week intervention implementation period with Group 2, Group 1 received a retention test, to establish what happened to the thinking skills of Group 1 during the period in which they were not exposed to the intervention. To explain the data gained through the test results, participants were requested to record their perceptions of and experiences related to the FIE programme in a narrative. This was used to determine more specifically which aspects of the programme the participants regarded as important and valuable, as well as to support the quantitative data obtained through the DAT-L tests.

The intervention period was geographically bound and kept short because Mouton (2009) suggests that a shorter, bounded implementation timeframe for an intervention decreases the influence of other factors on the research and enables one to make more reliable deductions regarding the impact on the intervention before it is implemented with larger groups. The elements of a plan as formulated by Feuerstein (1996, p. 33) were used as a basic point of departure for all the lessons. Learners had to define goals, look at available information, decide on the best strategy to be used, determine where to start, know the rules and check their work (Feuerstein, 1996). Manuals supplied with the instruments were used to guide the implementation of the programme activities meticulously according to a fixed procedure to make sure that both groups received the intervention in similar ways. Throughout, the principles of 
mediation were applied and learners were able to monitor, test and correct themselves. Unknown vocabulary, concepts and instructions were clarified and learners had the opportunity to work independently on the exercises. Learners had the opportunity to discuss problems in order to improve problem-solving behaviour and more importantly to become aware of their own cognitive behaviour during problem-solving (Savell et al., 1986, p. 386; Grosser, 1996, p. 77). Learners were encouraged to apply the knowledge gained from the instrument to real life situations.

\subsection{Population and sample}

The research was conducted at a South African university with a purposefully and conveniently selected sample consisting of all the second year education students with Mathematics as major $(n=24)$. These students were chosen due to the fact that one of the researchers lectured Mathematics to the students which made easy access to the students possible. Although students with Mathematics as major subject were used, the focus of this research was on the general development of cognitive skills irrespective of subject context. The students were randomly grouped into two groups, Group 1 and Group 2, comprising eleven and thirteen participants respectively. The participants were heterogeneous regarding the biographical variables gender, language and culture. As these groups were too small, the impact of these variables on the results was not determined. Only the impact of the independent variable, the FIE programme, with respect to the dependent variable, cognitive development, was established.

\subsection{Hypotheses}

As the study was pre-experimental in nature, only the following tentative null and directional and non-directional alternative hypotheses could be formulated.

$\left(\mathrm{H}_{0}\right)$ : The FIE programme of Reuven Feuerstein will have no statistical significant impact on the cognitive skills of prospective Mathematics educators.

$\left(\mathrm{H}_{\mathrm{a}}{ }^{1}\right)$ : The FIE programme of Reuven Feuerstein will have a statistical significant impact on the cognitive skills of prospective Mathematics educators.

$\left(\mathrm{H}_{\mathrm{a}}^{2}\right)$ : There is a relationship between the FIE programme of Reuven Feuerstein and the cognitive skills of prospective educators.

3.3 Data collection instruments

\subsubsection{DAT-L test}

With the assistance of the Human Sciences Research Council, the DAT-L test was identified as a suitable test to determine the cognitive development level of the participants (Owen \& Vosloo, 2008). The DAT-L test makes use of static assessment procedures, and supported the focus of the study, namely to determine cognitive development as product after the implementation of the intervention, in contrast to dynamic assessment procedures that rather aim to determine the potential for cognitive development (Colman, 2001; Tzuriel, 2009). 
The DAT-L is a set of six differential aptitude tests which focus on the following facets of cognitive functioning: vocabulary, verbal and non-verbal reasoning, computations, comprehension, comparison, spatial visualization, memory and mechanical insight (Owen \& Vosloo, 2008). For this research, the tests for verbal (Test 2) and non-verbal reasoning (Test 3) were used as they are related well to the skills used in the two instruments of the intervention programme, namely Organization of Dots and Analytic Perception.

The rationale for using Test 2 rests upon the assumption that certain skills are required to determine relationships and to solve problems which require logical thinking, and are required for successful general reasoning (Owen \& Vosloo, 2000: p.4). The test comprised twenty five questions and required the participants to understand, logically process and solve verbal problems. Feuerstein's instrument Organization of Dots, although non-verbal in nature, aims at helping learners to improve their skills to solve problems, organize information spontaneously, understand relationships, think logically, plan, categorize, analyse and summarize all of which can be applied across a variety of learning contexts (Feuerstein et al., 1983, p.140-141).

Test 3 aims to realize relationships between figures, to identify a missing figure and to follow changes that a figure can undergo in a pattern of figures (Owen \& Vosloo, 2000, p.5). This test consists of twenty five questions divided into two sections, A and B. In Section A, learners have to match figures and in section $\mathrm{B}$, they are expected to identify a missing figure when there is a change in figures. This test measures the skill to solve problems of a logical nature when no words or numbers are given. The improvement of non-verbal reasoning skills is addressed in the Feuerstein Instrument Analytic Perceptions (Feuerstein, 1996).

\subsubsection{Narrative analysis}

On completion of the research, all the participants wrote narratives that documented their perceptions and experiences with the FIE programme. The narratives focused on obtaining information regarding the four elements suggested by McMillan and Schumacher (2006, p. 62), namely detail about personal experiences during the intervention, particular incidents or experiences of importance during the intervention, the use of expressive language to describe what the intervention achieved and how meaningful the intervention appeared to be. By means of inductive analysis the researchers independently worked through the narratives and identified codes related to the aforementioned elements after which codes were compared and common themes identified (Cohen, Manion \& Morrison, 2007, p. 476).

\section{Reliability and validity of the DAT-L test}

The reliability of the test instrument for South African learners varies between Cronbach alpha coefficients of $0.55-0.67$ for verbal reasoning and $0.67-0.71$ for non-verbal reasoning and are regarded as satisfactory by the authors of the test (Owen, 2000, p. 43).

For the actual study Cronbach alpha coefficients of 0.59 and 0.24 were calculated for Test 2 and Test 3 respectively. The reliability for Test 3 is quite low, which could possibly be attributed to the fact that very few of the participants completed the test in the set time frame. If the last five test items of the test are not considered when calculating the Cronbach alpha coefficient, the reliability coefficient that is reflected is 0.70 . In most of the social sciences, a Cronbach alpha between 0.7 and 0.8 is regarded as acceptable. Some researchers, however, argue that 0.75 and 
0.80 are acceptable, and in some instances 0.60 is regarded as in order for an initial exploratory study, as was the case with this research (Garson, 2008; Simon, 2008).

In addition to the Cronbach alpha coefficients, reliability was also guaranteed by administering and marking the tests meticulously according to the instructions in the test manual. All the marks were checked twice to ensure reliability. There was only one correct answer and no marks were deducted for wrong answers. Tests were taken in classroom environments familiar to the learners to avoid the interference of unfamiliar circumstances (Cohen et al., 2007, p. 156160).

The following important aspects were considered to ensure reliability and validity for the testretest situation:

- The time interval between the two tests was short enough to prevent the possible influence of external factors and long enough so as to prevent the learners from remembering the questions from the first test.

- Tests were collected after administration and no answers were made available to the participants. The test questions were in no way related to the subject content whatsoever which could have benefitted the participants (Cohen et al., 2007, p. 146; Pietersen \& Maree, 2007a, p. 215; McMillan \& Schumacher, 2006, p. 140).

\section{Trustworthiness of the narratives}

To ensure the trustworthiness of the narratives, the completion of which was a subjective process, the following guidelines as indicated by Nieuwenhuis (2007, p. 113-115) were followed: the coded data was verified by an independent coder to eliminate researcher bias. In addition to this, the findings were not used to generalize to other populations. The researchers merely wanted to determine the effect of the intervention and the experiences that the participants had with the intervention in the bounded geographical context of a specific South African university. An inductive process of data analysis was followed to ensure that meaning and understanding were derived from the exact words of the participants.

\subsection{Ethical considerations}

The participants were informed about the nature of the study and what their involvement would entail in order firstly to obtain their assent as to whether they would like to take part or not. The participants were also assured that their responses would remain confidential and anonymous and that they would be informed about the outcome of the study. After obtaining assent, written consent was obtained from all the participants involved in the research.

\section{Data Analysis and Discussion}

\subsection{Data analysis and interpretation of the DAT-L pre-test and post-test results}

Data analysis was conducted through standardized descriptive and inferential statistical procedures by an independent statistician. Non-parametric statistical procedures were used due to the small sample $(\mathrm{n}<30)$ and due to the fact that it could not be presumed that the study variables were normally distributed (McMillan \& Schumacher, 2006, p. 308; Pietersen \& Maree, 2007b, p. 233). The Mann-Whitney test which is a non-parametric equivalent of the parametric t-test was used to compare the pre-test and post-test results of the two independent groups, Group 1 and Group 2 (Pietersen \& Maree, 2007b, p. 233). The Mann-Whitney test 
uses ranks rather than real values. This implies that extreme values will have a lesser impact on results than the parametric t-test (Pietersen \& Maree, 2007b, p. 233). The Wilcoxon signedrank test, a non-parametric test similar to the parametric t-test, was used to compare the differences between the pre-test and post-test results within the groups. Table 1 reports on the pre- and post-test results of Group 1 and Group 2.

\begin{tabular}{|l|l|l|l|}
\hline Group 1 & N & Mean (25) & Standard deviation \\
\hline Pre-test Test 2 & 11 & 14.0 & 4.754 \\
\hline Pre-test Test 3 & 11 & 9.6 & 3.613 \\
\hline Post-test Test 2 & 11 & 15.8 & 4.792 \\
\hline Post-test Test 3 & 11 & 11.2 & 3.894 \\
\hline Retention test Test 2* & 11 & 15.8 & 5.016 \\
\hline Retention test Test3* & 11 & 15.0 & 4.195 \\
\hline Group 2 & $\mathbf{N}$ & Mean (25) & Standard deviation \\
\hline Pre-test Test 2 & 13 & 12.9 & 2.929 \\
\hline Pre-test Test 3 & 13 & 10.3 & 3.966 \\
\hline Post-test Test 2 & 13 & 15.4 & 2.434 \\
\hline Post-test Test 3 & 13 & 13.5 & 4.594 \\
\hline
\end{tabular}

Table 1: Pre- and post-test results of participants

* Retention test only applicable to Group 1

The standard deviation is an indication of the variance of scores around the mean (Coolidge, 2006, p. 76). The larger the standard deviations, the further the values lie from the arithmetic mean (Steyn, Smit, Du Toit \& Strasheim, 2004, p.137). The standard deviations revealed that there was not a large variance in the pre- and post-test results for both groups, which indicated that the participants were more or less on the same cognitive developmental level and thus comparable.

Although the researchers did not focus on Mathematics as a subject in particular, the low mean scores obtained in the pre-tests by the participants is distressing when taking into consideration that these were second-year education students with Mathematics as major, a subject that, as prerequisite for effective learning, expects learners to have a variety of well developed cognitive skills (Winicki-Landman, 2001, p. 30; Sing et al., 2002, p. 324; Winstead, 2004, p. 44, Department of Education, 2007, p. 4; Sezer, 2008, p. 351).

The mean of the-pre test for Group 1 (14.0) is higher than the mean of the pre-test of Group 2 (12.9) for test 2. Although the results for Group 1 were better than those of Group 2, it appeared as if participants in both groups could improve regarding cognitive skills such as logical thinking and general reasoning which were tested with Test 2. The mean of the post-test of Group 1 for Test 2 (15.8) was higher than that of Group 2 (15.4), and when comparing this with the pre-test results, it seemed as if there was an improvement in the application of cognitive skills.

The mean of the post-test of both groups was greater than the mean of the pre-test, which might point out that the intervention programme possibly, has the potential to improve the cognitive skills. This augurs well for findings in the literature that highlight the merits of the FIE 
programme for improving cognitive development (Feuerstein et al., 1981, p. 282; Savell et al., 1986, p. 390; Toomey et al., 2000; Kozulin, 2008).

Regarding the pre- and post-test results of both groups for test 3, it is important to mention that the means of the post-test were very low at 9.6 and 10.3 respectively. It seems as if the nonverbal skills were more problematic than the verbal skills. An improvement was, however, noted for both groups in the post-tests with means of 11.2 and 13.5 respectively. The improvement of the means of Group 1 regarding Test 3, from the post-test (11.2) to the retention test (15.0), as well as the fact that the post-test mean for Test 2, remained the same during the retention test. This result could point in the direction that Feuerstein's intervention programme possibly has the potential to improve the application of cognitive skills, but also that these skills, when established, could be retained in the absence of direct mediation and result in autonomous cognitive behaviour (Feuerstein et al., 1983, p. 115-118).

Inferential statistics assisted the researchers to provide deeper dimensions to the results and to ultimately accept or reject the hypotheses. The Mann Whitney test, a non-parametric t-test for independent groups was used (Pietersen \& Maree, 2007b:, p. 233) to indicate significant differences between groups 1 and 2. Table 2 reports the results for the differences between the different test occasions for Group 1 and Group 2.

\begin{tabular}{|c|c|c|c|c|c|}
\hline & $\mathbf{N}$ & $\begin{array}{l}\text { Median } \\
\text { rank }\end{array}$ & $\begin{array}{l}\text { Mann- } \\
\text { Whitney } \\
\text { U }\end{array}$ & $\begin{array}{l}\text { Z (Mann- } \\
\text { Whitney } \\
\text { statistics) }\end{array}$ & $\begin{array}{l}\text { Statistical } \\
\text { significance }(p)\end{array}$ \\
\hline Pre-test Test 2 Group 1 & 11 & 12.68 & \multirow{2}{*}{69.500} & \multirow{2}{*}{-.117} & \multirow{2}{*}{.910} \\
\hline Pre-test Test 2: Group 2 & 13 & 12.35 & & & \\
\hline Pre-test Test 3: Group 1 & 11 & 11.77 & \multirow{2}{*}{63.500} & \multirow{2}{*}{-.468} & \multirow{2}{*}{.649} \\
\hline Pre-test Test 3: Group 2 & 13 & 13.121 & & & \\
\hline Post-test Test 2 Group 1 & 11 & 12.50 & \multirow{2}{*}{71.500} & \multirow{2}{*}{.000} & \multirow{2}{*}{1.000} \\
\hline Post-test Test 2: Group 2 & 13 & 12.50 & & & \\
\hline Post-test Test 3: Group 1 & 11 & 10.73 & \multirow{2}{*}{52.000} & \multirow{2}{*}{-1.142} & \multirow{2}{*}{.277} \\
\hline Post-test Test 3: Group 2 & 13 & 14.00 & & & \\
\hline
\end{tabular}

Table 2: Significance of differences between the pre- and post-test means when using the Mann-Whitney test

Statistical significance: ${ }^{*} \mathrm{p}<0.05$

The data tabled above, indicate that there was no statistical significance between Groups 1 and 2 , as $\mathrm{p}>0.05$ for all the different test occasions. This implies that not one of the groups benefitted more than the other from the intervention programme. 
The non-parametric Wilcoxon Signed ranks test was used to compare the improvement of cognitive skills within the groups. The results are reported in Table 3.

\begin{tabular}{|c|c|c|c|c|c|}
\hline \multirow{2}{*}{ Group 1} & \multirow{2}{*}{$\mathbf{N}$} & \multicolumn{2}{|c|}{ Mean rank } & \multirow{2}{*}{$\mathrm{Z}$} & \multirow{2}{*}{$\begin{array}{l}\text { Statistical } \\
\text { significance }\end{array}$} \\
\hline & & Negative & Positive & & \\
\hline Pre-test Test 2 & 11 & \multirow{2}{*}{2.83} & \multirow{2}{*}{6.64} & \multirow{2}{*}{-1.946} & \multirow{2}{*}{.052} \\
\hline Retention test Test 2 & 11 & & & & \\
\hline Pre-test Test 3 & 11 & \multirow{2}{*}{.00} & \multirow{2}{*}{5.50} & \multirow{2}{*}{-2.810} & \multirow{2}{*}{$.005^{*}$} \\
\hline Retention test Test 3 & 11 & & & & \\
\hline Post-test Test 2 & 11 & \multirow{2}{*}{6.75} & \multirow{2}{*}{4.67} & \multirow{2}{*}{-.052} & \multirow[b]{2}{*}{.959} \\
\hline Retention test Test 2 & 11 & & & & \\
\hline Post-test Test 3 & 11 & \multirow[b]{2}{*}{2.00} & \multirow[b]{2}{*}{6.89} & \multirow[b]{2}{*}{-2.585} & \multirow[b]{2}{*}{$.010^{*}$} \\
\hline Retention test Test 3 & 11 & & & & \\
\hline Pre-test Test 2 & 11 & \multirow[b]{2}{*}{2.00} & \multirow[b]{2}{*}{6.38} & \multirow[b]{2}{*}{-2.414} & \multirow{2}{*}{$.016^{*}$} \\
\hline Post-test Test 2 & $\frac{11}{11}$ & & & & \\
\hline & & \multirow{3}{*}{2.00} & \multirow{3}{*}{6.38} & \multirow{3}{*}{-2.434} & \\
\hline Pre-test Test 3 & 11 & & & & \multirow{2}{*}{$.015^{*}$} \\
\hline Post-test Test 3 & 11 & & & & \\
\hline \multirow{2}{*}{ Group 2} & \multirow{2}{*}{$\mathbf{N}$} & \multicolumn{2}{|c|}{ Mean rank } & \multirow{2}{*}{$\mathrm{Z}$} & \multirow{2}{*}{$\begin{array}{l}\text { Statistical } \\
\text { significance }\end{array}$} \\
\hline & & Negative & Positive & & \\
\hline Pre-test Test 2 & 13 & \multirow{2}{*}{.00} & \multirow{2}{*}{7.00} & & $001^{*}$ \\
\hline Post-test Test 2 & 13 & & & -3.198 & .001 \\
\hline Pre-test Test 3 & 13 & & & & \\
\hline Post-test Test 3 & 13 & 2.00 & 7.91 & -2.909 & $.004^{*}$ \\
\hline
\end{tabular}

\section{Table 3: Significance of differences between pre- and post-test means within groups} as measured by the Wilcoxon Signed ranks test

Statistical significance: ${ }^{*} \mathrm{p}<0.05$

From the results reported in Tables 2 and 3 it is clear that the statistical significant differences in test results did not occur between the two groups, but mainly within the two groups. Regarding Group 1, the post-test results of Test 2 were statistically significantly better than the pre-test results for Test 2 of Group 1, as $\mathrm{p}=0.016$. The same applied for Test 3, where a statistical significant improvement was noted for the post-test results, as $p=0.015$. No statistical significant difference was noted between the retention test and the post-test results for Test 2 and the retention and pre-test results of Test 2. The cognitive skills did not weaken or improve further during the retention period. A statistically significant difference is again noted between the retention test and the pre-test results of Test $3(\mathrm{p}=0.005)$, as well as between the retention test and the post-test of Test $3(\mathrm{p}=0.010)$, in favour of the retention test results. This implies that once the cognitive skills were established, they were retained and improved, possibly through continuous use. 
A similar trend was noted for Group 2. There was a statistically significant difference between the pre- and post-test results of Group 2 for Test 2, $\mathrm{p}=0.001$, as well as between the pre- and post-tests of Test 3, $p=0.004$. The statistically significant differences confirm that the FIE programme possesses the latent potential to improve cognitive ability (Toomey et al., 2000; Kozulin, 2008).

The test results of Group 1 and Group 2 indicate that cognitive development does not happen at once. Cognitive development takes time and requires purposeful efforts for extensive practice in applying acquired cognitive skills (Van den Berg, 2004, p. 280; Rudd, 2007, p. 46). It is disturbing that the test results for the pre-test indicated that the participants lacked verbal and non-verbal cognitive and meta-cognitive skills and strategies (Beyer, 1987, p. 17; Monteith, 2002: p. 97; Thornton, 2002, p.102; Grabe \& Grabe, 2004, p. 47-49; Van den Berg, 2004, p. 279-280; Gelter, 2003, p. 337; Bereiter, 2006, p. 14; Halpern, 2007, p. 10; Kok, 2007, p. 28-30). Without well developed cognitive and meta-cognitive skills and strategies, the participants would not be able to function as self-regulated learners who can independently construct knowledge with understanding (Gouws, 1998, p. 72, 73; Doolittle, 2000; Eggen \& Kauchak, 2004, p. 28; Woolfolk, 2004, p. 323; Bjorklund, 2005, p. 81; Langford, 2005, p. 234, 235; Kok, 2007, p. 64-44; Ormrod, 2008, p. 29, 196). In support of Lombard and Grosser (2004, p.213), the researchers argue that, if the participants are not equipped with these skills, they will not be able to nurture these skills among their learners one day, and the critical outcomes of the National Curriculum Statement, which envisage all learners as competent in the solving of problems, effective in the collection, organizing and managing of activities and successful in evaluating and applying information critically (Department of Education, 2003a, p. 2), will not become a reality.

The improvement in the post-test results supports the view of Feuerstein et al. (1983, p. 59) who argue that the cognitive potential of learners is not static and fixed, but dynamic in nature.

\subsection{Data analysis and interpretation of the narratives}

After the intervention period, the participants were asked to write down their perceptions of and experiences with the FIE programme. The aim was to determine whether the narratives confirmed the quantitative test results before final conclusions could be made. An inductive analysis procedure was used to analyse information obtained from the participant's experiences of the intervention. Main ideas or codes from each participant's narrative were identified and themes were developed regarding person, incidents, language and experiences from the intervention. The participants indicated inter alia that they could manage themselves better, that their self-confidence increased and that their problem-solving and decision-making skills improved. In addition to this, their speed in the execution of tasks improved, they considered more than one solution to a problem, could change their strategies, did not give up in difficult situations, thought about the steps involved in problem-solving, could apply the cognitive skills addressed in the instruments to real life situations, worked less impulsively, thought a problem through, avoided mistakes, paid attention to detail, checked their work, considered what was given before starting with their tasks, thought critically about information, defined a goal and admitted that planning plays an important role in success. Participants were positive about the programme and commented that it also helped them to reflect on their own lives because they would now be able to identify mistakes they have made in their own lives and think about their mistakes differently. They also mentioned that the programme helped them with intrinsic motivation and persistence on tasks. 
The participants' personal experiences indicate changes and improvement with regard to the cognitive functions that are required in the input, elaboration and output phases of the learning process, as highlighted by Feuerstein et al. (1983, p. 73); Feuerstein et al. (1985, p. 52-53) and Feuerstein (2007, p. 5). Furthermore, the researchers argue that the improved cognitive functions as documented by the participants in their narratives could have attributed to the improvement noted in the post-test results of the participants. The researchers link their argument to the views of Fisher (1990, p. 132) and Feuerstein $(2007$, p. 5) who indicate that cognitive development and improvement occur when cognitive deficiencies linked to the input, elaboration and output phases of the learning process are ameliorated.

The researchers cautiously assumed that the participants lacked exposure to mediated learning experiences. They base their argument on the fact that the narratives indicated that the participants acquired important cognitive and meta-cognitive skills and strategies that are necessary for cognitive development through the mediated learning approach on which the intervention was based. Participants mentioned in their narratives that they now realise the importance of planning their work, using different strategies to solve problems, reflecting on their work and linking what they have learned to real life situations, which links well with what Fraser (2006, p.9) indicates as some of the merits of mediated learning.

\subsection{Accepting/rejecting hypotheses}

At the onset of the study tentative null and alternative hypotheses were formulated. Based on the statistically significant results that were obtained, and acknowledging the fact that other biographical variables could have impacted on the results, the researchers cautiously reject the null and non- directional alternative hypothesis. They accept the directional alternative hypothesis as statistically significant improvement after the implementation of the intervention was noted between Group 1 and Group 2 for all the test occasions, with the exception of pretest 2 and the retention test 2, as well as post-test 2 and the retention test 2 results for Group 1 .

\section{Findings}

Although this research was an exploratory pilot study with a number of limitations linked to the sampling procedure and the type of experimental design used, a number of important conclusions can be derived from this research that should be followed up in more comprehensive studies.

The researchers argue that, in a competitive society, intelligence on its own is not sufficient and learners need to purposely develop cognitive skills in order to solve problems and reason in a rapidly changing world. Educators need to support learners in the development of these skills and they should therefore acquire skills like analysis, synthesis, reasoning and problem-solving themselves before conveying these skills to their learners.

Our aim was to establish whether prospective educators possess cognitive skills as well as the potential of the FIE programme to develop and improve cognitive skills. The pre-test results revealed that the prospective Mathematics educators who took part in the study, did not possess adequate cognitive and meta-cognitive skills and strategies. These results create reason for concern as it appears that the educators who taught these learners at school, as well as the lecturing they received during their first year at university, did not purposefully create 
opportunities to enhance their cognitive development. Based on the results of this research, it is clear that educator training should devote much more attention to the cognitive development of prospective educators.

This research revealed that low cognitive performance is reversible through mediation. This implies that instead of labelling the cognitive skills of prospective educators as inadequate, emergent or latent, a pro-active mediated learning approach during the training of these educators should be adopted to improve their cognitive skills. Prospective educators who experience problems in executing cognitive skills for the completion of academic tasks, should be exposed to mediated learning on a more frequent basis, as well developed cognitive skills are regarded as pivotal to educators' teaching effectiveness (Birjandi \& Bagherkazemi, 2010, pp. 135-145; Elizabeth, May \& Chee, 2008, pp. 43-57; Hashemi, 2008; Korthagen, 2004, pp. $77-$ 79; Tamblyn, 2000, pp. 16-19). In addition to this, well developed cognitive skills are needed to avoid student educators falling into working ways which are disorganized, overly simplistic, spotty about getting facts, apt to apply unreasonable criteria and then becoming easily distracted, ready to give up at the least hint of difficulty and being intent on a solution that is more detailed than possible or being satisfied with an overly generalized and uselessly vague response (Facione, 2009, p. 10).

According to a mediated learning approach the purpose of teaching and learning should focus on teaching prospective educators how to think and not what to think. It is imperative that skills such as analysis, reflection, evaluation, making valid conclusions and problem-solving need to be nurtured among prospective educators. In addition to this, prospective educators need to be made aware of the fact that deficient cognitive skills can contribute to poor academic performance. These deficient cognitive skills refer inter alia to impulsive ways of working, inaccuracy, the inability to distinguish between relevant and irrelevant facts, and a lack of selfregulation during learning (Feuerstein, 2007, p. 5). In essence, when complying with the aforementioned important challenges, educator training will equip teachers to lay the foundation for enhancing cognitive development among learners at school.

\section{Conclusion}

In order to provide quality education at school level and to develop learners to become competent thinkers and problem solvers, a qualitative improvement in the training of educators will have to take place. Teacher education institutions are therefore faced with a two folded challenge, namely (a) to motivate student educators that the teaching of thinking skills is important and that it can be done, and (b) to equip student educators with skills so that they become effective thinkers themselves. It could be argued that educators should become effective thinkers themselves before they can teach learners how to become effective thinkers. The researchers are convinced that the FIE programme has the potential to enhance cognitive development, and should therefore be utilized during the training of educators.

\section{References}

Barnes, C.A. (2005). Critical thinking revisited: past, present and future. New directions for community colleges, 130:5-13.

Bauer, P.J. (2006). Early memory development. In U. Goswani (Ed.), Childhood cognitive development (pp. 127-147). Australia: Blackwell Publishing. 
Bereiter, C. (2006). Reflections on depth. In K. Leithwood, P. McAdie, N. Bascia,. \& A. Rodrigue (Eds.). Teaching for deep understanding: What every educator should know (pp. 11-16). Thousand oaks, CA.: Corwin Press.

Beyer, B.K. (1987). Practical strategies for teaching of thinking. Boston: Allyn and Bacon. 273 p.

Beyer, B. K. (1991). Practical strategies for the direct teaching of thinking skills. In E.L. Costa (Ed.), Developing minds. A resource book for teaching thinking. Revised edition, Volume 1 (pp. 274-279). Alexandria, Virginia: Association for supervision and curriculum development.

Birjandi, P. \& Bagherkazemi, M. (2010). The relationship between Iranian EFL Teachers'critical thinking ability and their professional success. English language teaching, 3(2), pp. 135-145.

Bjorklund, D.F. (2005). Children's thinking. Cognitive development and individual differences. USA: Thomson Wadsworth. 507 p.

Cohen, L., Manion, I., \& Morrison, K. (2007). Research methods in education. 6th ed. London: Routledge. 638 p.

Colman, A.M. (2001). Dynamic testing. Retrieved Feb. 232009 from http://www.encyclopedia.com/ doc/1087-dynamictesting.html

Coolidge, F.L. (2006). Statistics. A gentle introduction. 2nd ed. London: Sage Publications. $396 \mathrm{p}$.

Davis, G. (2009). Independent Political Bureau Retrieved Jun. 2009 from http://www.iol.co.za/index.php?set_id=1\&click_id=105\&art_id=nw20090603133123 785C963029

Department of Education see South Africa. Department of Education.

Donald, D., Lazarus, S., \& Lolwana, P. (2004). Educational psychology in social context. Oxford: University Press. $378 \mathrm{p}$.

Doolittle, P.E. (2000). Constructivist pedagogy. Retrieved Jun. 142008 from http://edpsychserver.ed.vt.edu/workshops/tohe1999/pedagogy.html

Eggen, P., \& Kauchak, D. (2004). Educational Psychology: windows on classrooms. Upper Saddle River, N.J.: Pearson, Merrill Prentice Hall. 568 p.

Egozi, M. (1994). Instrumental enrichment and mediation. In R. Feuerstein (Ed.), Mediated learning experience (MLE): theoretical, psychosocial and learning implications (pp. 347364). England: Freud Publishing House.

Elder, L., \& Paul, R. (2004). Thinker's guide series / Critical thinking concepts and tools. Foundation for critical thinking. $368 \mathrm{p}$.

Elizabeth, C. L., May, C. M. \& Chee, P. K. (2008). Building a model to define the concept of teacher success in Hong Kong. Teaching and teacher education, 24, 623-634.

Engelbrecht, P. (1995). Teaching children to think: The South African experience.

Newsletter of the international association for cognitive education, 5(4):11-12.

Facione, P. A. (2009). Critical thinking: what it is and why it counts. 2009 Update, 1-23. 
Falik, L. (2001). Using MLE parameters to change children's behaviour: Technique for parents and childcare providers. Retrieved May 292008 from http://www.icelp.org.

Feuerstein, R. (2008). Structural cognitive modifiability. http://www.icelp.org/asp /Basic Theory.shtm. Date of access: 7 Mar. 2008.

Feuerstein, R. (2007). The Feuerstein instrumental enrichment programme (FIE). Instrumental materials: Level 1 Training. Israel: ICELP. Workshop presented by Lilian Lomofsky, Jun 2008.

Feuerstein, R. (1996). FIE Instruments. Retrieved May 72008 from http://www.3d-ring. org/cep/instruments.asp

Feuerstein, R. (1982). The dynamic assessment of retarded performers. Baltimore: University Park Press. 413 p.

Feuerstein, R., Hoffman, M.B., Jensen, M.R., \& Rand, Y. (1985). Instrumental enrichment, An intervention programme for structural cognitive modifiability: Theory and practice. In J.W. Segal (Ed.), Thinking and learning skills. Volume 1. Relating instruction to research (pp. 43-82). Hillsdale, New Jersey: Lawrence Erlbaum Associates.

Feuerstein, R., Miller, R., Hoffman, M.B., Rand, M.B., Mintzker, M.A., \& Jensen, M. (1981). Cognitive modifiability in adolescence: Cognitive structure and the effects of intervention. The journal of special education, 15(2): 269-287.

Feuerstein, R., Rand, Y., HoffmaN, M.B., \& Miller, R. (1983). Instrumental enrichment: An intervention programme for cognitive modifiability. Baltimore: University Park Press. 436 p.

Fisher, R. (1990). Teaching children to think. England: Basil Blackwell. 272 p.

Fosnot, C.T. (1989). Enquiring teachers, enquiring learners: A constructivist approach for teaching. New York: Teachers College, Columbia University. 170 p.

Fraser, J.D.C. (2006). Mediation of learning. In M.M. Nieman, \& R.B. Monyai, R.B., The educator as mediator of learning ( $p$. 1-21). Pretoria: Van Schaik.

Garson, D. (2008). Reliability analysis. Retrieved Aug. 92008 from http://www/2.chass.z.ncsu. edu/garson

Gelter, H. (2003). Why is reflective thinking uncommon? Reflective practice, 4(3):337-344, Oct.

Gouws, A. (1998). Turning information into accurate and useful knowledge In N. Kruger, \& H. Adams, Psychology for teaching and learning: what teachers need to know (pp.61-75). Sandton: Heinemann.

Grabe, M. \&, Grabe, C. (2004). Integrating technology for meaningful learning. $4^{\text {th }}$ ed. New York: Houghton Mifflin. $461 \mathrm{p}$.

Grosser, M.M. (1996). Die belangrikheid van kognitiewe ontwikkelingsprogramme by studente aan onderwyskolleges. Vista. (Verhandeling-M Ed.) $144 \mathrm{p}$.

Halpern, D.F. (2007). The nature and nurture of critical thinking. In R.J. Sternberg, H.L. Roediger, \& D.F. Halpern, D.F (Eds.), Critical thinking in psychology (pp.1-14). New York: Cambridge.

Hashemi, M. (2008). On the role of teachers' emotional intelligence on their pedagogical success. Unpublished M.A. Thesis. Tehera: Allame Tabataba'l University. 
Haywood, H.C., Burns, S., Arbitman-Smith, R., \& Delclos, V.R. (1984). Forward to fundamentals: Learning and the 4th R. Peabody journal of education, 61(3):16-35, Spring.

Howie, S.J. (2007). Third International Mathematics and Science Study-Repeat (TIMSS-R): What has changed in South African pupils' performance in mathematics between 19951998? Retrieved Aug.10 2007 from http://academic.sun.ac.za/ mathed/AMESA/TIMSSR.htm

Ivankova, N.V., Creswell , J.W., \& Plano Clark, V.L. (2007). Foundations and approaches to mixed method research In K. Maree (Ed.), First steps in research (pp. 254-265). Pretoria: Van Schaik.

Kok, I. (2007). Vraagstelling as effektiewe onderrigleervaardigheid om leerders se hoërorde-denke in die natuurwetenskappe-leerarea te ontwikkel. Potchefstroom: Noordwes Universiteit. (Verhandeling - D.Phil.) 280 p.

Korthagen, F. A. (2004). In search of the essence of a good teacher: towards a more holistic approach in teacher education. Teaching and teacher education, 20, 7-97.

Kozulin, A. (2008). Culturally different students. Retrieved May 282008 from http://111.icelp.org/asp/Aspects of Mediated Learning_Experience.shtm.

Langford, P.E. (2005). Vygotsky's developmental and educational psychology. New York: Psychology Press. $251 \mathrm{p}$.

Le Roux, A., Olivier, A., \& Murray, H. (2004). Children struggling to make sense of fractions: an analysis of their argumentation. South African journal of education, 24(1):88-94.

Link, F.R. (1991). Instrumental enrichment. In A.L. Costa (Ed.), Developing minds: programs for teaching thinking. Revised edition, Volume 2 (pp.9-11). Alexandria, Virginia: Association for supervision and curriculum development.

Lombard, B.J.J. \& Grosser, M.M. (2008). Critical thinking: are the ideals of OBE failing us or are we failing OBE? South African journal of education, 28:561-579.

Lombard, B.J.J. \& Grosser, M.M. (2004). Critical thinking abilities among prospective educators: ideals versus realities. South African journal of education, 24(3):212-216.

Maree, J.G., Molepo, J.M., Owen, J.H., \& Ehlers, R. (2005). 'n Probleemgebaseerde benadering tot wiskunde in graad 9 en 11 in die Limpopo-provinsie. Suid Afrikaanse tydskrif vir natuurwetenskap en tegnologie, 24(4):124-133.

Matthews, C. (2001). Dr Feuerstein's miracles. Reader's Digest: 147-153, Nov.

McMillan, J.H., \& Schumacher, S. (2006). Research in education: Evidence-based inquiry. 6th ed. Boston: Allyn and Bacon. 517 p.

Monteith, J.L de K. (2002). How to become an effective learner. In N. Kruger, \& H.M. Adams (Eds.), Psychology for teaching and learning: what teachers need to know (pp. 91106). Sandton: Heinemann.

Mouton, J. (2009). Monitoring and evaluating educational interventions. Paper presentation at the national conference of the International Association for Cognitive Education in Southern Africa. 11-13 February 2008. Royal Cape Yacht Club, Cape Town, South Africa. 
Nickerson, R.S., Perkins, D.N., \& Smith, E.E. (1985). The teaching of thinking. London: Lawrence Erlbaum Associates. 383 p.

Nieuwenhuis, J. (2007). Analysing qualitative data. In K. Maree (Ed.), First steps in research (pp. 98-122). Pretoria: Van Schaik.

Ormrod, J.E. (1995). Educational psychology. Principles and applications. New Jersey: Merrill Prentice Hall. 662 p.

Ormrod, J.E. (2008). Educational psychology. Developing learners. 6th edition. New Jersey: Merrill Prentice Hall. 627 p.

Owen, K. (2000). Handleiding vir die Differensiële aanlegtoets (Gevorderd) DAT Vorm L. Pretoria: Raad vir geesteswetenskaplike navorsing. 53 p.

Owen, K., \& Vosloo, H.N. (2008). (webmaster@mindmuzik.com) 17 Jan. 2008. Differential Aptitude Tests - Forms R, S, K and L (DAT). E-pos aan: Kloppers, M.M. (Magda.Kloppers@nwu.ac.za)

Owen, K., \& Vosloo, H.N. (2000). Differensiële aanlegtoetse Vorm L. Differential Aptitude Tests Form L. Pretoria: Raad vir geesteswetenskaplike navorsing. $110 \mathrm{p}$.

Peretti, P.O., \& Austin, S. (1980). Cultural deprivation reflected in linguistic acquisition and development. Social behavior and personality, 8(2):225-227.

Pietersen, J., \& Maree, K. (2007a). Standardisation of a questionnaire. In K. Maree (Ed.), First steps in research (pp. 215-221). Pretoria: Van Schaik.

Pietersen, J., \& Maree, K. (2007b). Overview of statistical techniques. In K. Maree (Ed.), First steps in research (pp. 215-252). Pretoria: Van Schaik.

Pithers, R.T., \& Soden, R. (2000). Critical thinking in education: a review. Educational research, 42(3):237-249.

Pratt, D.D. (2005). Good teaching: One size fits all. In J. Ross-Gordon (Ed.), An up-date on teaching theory. San Francisco: Jossey-Mass. Retrieved Feb. 222009 from http://teachingperspectives.com/fdf/goodteaching.

Rotterdam, H. (2000). The taxonomy of cognitive objectives and the theory of structural cognitive modifiability. Bloom and Feuerstein:1-13. Retrieved May 12008 from www.icelp.org/files/research/Bloom and Feuerstein.pdf

Rudd, R.D. (2007). Defining critical thinking. Techniques:46-49, Oct.

Savell, J.M., Twohig, P.T., \& Rachford, D.L. (1986). Empirical status of Feuerstein's "Instrumental Enrichment " (FIE) Technique as a method of teaching thinking skills. Review of Educational Research, 56(4):381-409, Winter.

Schayer, M. (2000). Piaget and Vygotsky. A necessary marriage for effective education intervention. In L. Smith (Eds.), Piaget, Vygotsky and beyond. Future issues for developmental psychology and education. (pp. 36-59).

Schraw, G., \& Olafson, L. (2002). Teachers' epistemological world views and educational practices. Journal of cognitive education and psychology, 8(2):99-148.

Schraw, G., \& Olafson, L. (2003). Teachers' epistemological world views and educational practices. Journal of cognitive education and psychology, 3(2):178-239, Sept.

Sezer, R. (2008). Integration of critical thinking skills into elementary school teacher education courses in Mathematics. Journal of education, 128(3):349 - 362, Spring. 
Sharron, H. (1987). Changing children's minds: Feuerstein's revolution in the teaching of intelligence. London: Souvenir Press. 336 p.

Sigel, I.E. (1991). Parents' influence on their children's thinking. In E.L. Costa (Ed.), Developing minds. A resource book for teaching thinking. Revised edition, Volume 1 (pp. 43-46). Alexandria, Virginia: Association for supervision and curriculum development.

Simon, S. (2008). What's a good value for Cronbach's alpha? Retrieved Aug. 9, 2008, from http://www.childrensmercy.org/stats

Sing, C.C., \& Khine, M.S. (2008). Assessing the epistemological and pedagogical beliefs among pre-service teachers in Singapore. In M.S. Khine (Ed.), Knowing, knowledge and beliefs. Epistemological studies across diverse cultures (pp. 287-299). Australia: SpringerVerlag. p. 287-299.

Singh, K., Granville, M., \& Dika, S. (2002). Mathematics and science achievement: Effects of motivation, interest and academic engagement. Journal of educational research, 95(6):323 (10 p.), Jul/Aug. Retrieved Mar. 22 2005, from EBSCOHost : Academic Search Premier, Full display : http://www-sa.ebsco.com

Skuy, M., Lomofsky, L., Fridjhon, P. \& Green, L. (1993). Effectiveness of Instrumental Enrichment for pre-service teachers in a disadvantaged South African community. International journal of cognitive education and mediated learning, 3(2):92-108.

Sonn, R.A. (2000). The need for different classroom settings for effective development of thinking skills. Journal of cognitive education and psychology, 1(2):257-265, Dec.

South Africa. Department of Education. (2003a). National curriculum statement grades 10-12 (General). Mathematics. Pretoria: Government Printer. 94 p.

South Africa. Department of Education. (2003b). Hersiene Nasionale kurrikulumverklaring Graad R-9 (Skole). Wiskunde. Pretoria: Government Printer. $114 \mathrm{p}$.

South Africa. Department of Education. (2007). Release of the 2007 matric examination $\begin{array}{lllll}\text { results. } & \text { Retrieved } & \text { Feb. } & 12 & 2008 \text { from: }\end{array}$ http://www.gautengonline.gov.za/portal/dt? serviceAction= speechDetails\&smID=GPGSPEECHANDMEDIA 408902.

Steyn, A.G.W., Smit, C.F., Du Toit, S.H.C., \& Strasheim, C. (2004). Moderne statistiek vir die praktyk. 6de uitg. Pretoria: Van Schaik. 761 p.

Tamblyn, P. (2000). Qualities of success: Lessons from a teacher career. Education Canada, 40(1), 16-19.

Thornton, S. (2002). Growing minds. An introduction in cognitive development. New York: Palgrave Macmillan. 218p.

Toomey, R., Smyth, C.E., Warner, C., \& Fraser, D. (2000). ICT and the quality of learning: A case study of ICT and school improvement at Glen Waverley Secondary College, Victoria, Australia. Retrieved May 11 2008, from http://www.oecd.org/dataoecd/32/31/2732716.pdf.

Tzuriel, D. (2009). Assessment - Dynamic assessment. Retrieved Jan. 3 2009, from http://education.stateuniversity.com/pages/1766/Assessment-DYNAMICASSESSMENT.html 
Vakalisa, N.C.G. (2007). Participative teaching. In M. Jacobs (Ed.), Teaching-learning dynamics: A participative approach for OBE. 3rd ed. (pp.1-33). Sandton: Heinemann.

Van den Berg, G. (2004). The use of assessment in the development of higher-order thinking skills. Africa education review, 1(2):279-294.

Van den Berg, M.E.S. (2000). Is there a need for critical thinking skills' modules at tertiary level? South African journal of higher education, 14(1):96:107.

Van der Walt, M., \& Maree, K. (2007). Do mathematics learning facilitators implement metacognitive strategies? South African journal of education, 27(2):223-241.

Winicki-Landman, G. (2001). Shh... Let them think... Let them talk! Australian Senior Mathematics Journal, 15(2):30 (8 p.). Retrieved Mar.17 2005, from EBSCOHost Academic Search Premier, Full display: http://www-sa.ebsco.com.

Winstead, L. (2004). Increasing academic motivation and cognition in reading, writing and mathematics: Meaning-making strategies. Educational Research Quarterly, 28(2):30 (20 p.), Dec. Retrieved Mar.17 2005, from EBSCOHost Academic Search Premier, Full display: http://www-sa.ebsco.com.

Wittrock, M.C. (1991). Models of heuristic teaching. In K. Marjoriebanks (Ed.), The foundations of students' learning (pp. 73-87). Oxford: Pergamon Press.

Woolfolk, A.E. (2004). Educational Psychology. Massachusetts: Allyn \& Bacon. 597 p.

Wragg, E.C., \& Brown, G. (2001). Questioning in the secondary school. London: Routledge/Falmer. 70 p. 